\title{
HOW NATURAL IS NATURAL? \\ HISTORICAL PERSPECTIVES ON WILDLIFE AND THE ENVIRONMENT IN BRITAIN
}

\section{Colin Matthew Memorial Lecture}

\author{
By Tom Williamson \\ READ 17 OCTOBER 2018
}

\begin{abstract}
This article explores some of the ways in which historians can, and should, engage with current debates about the environment. What we often think of as 'natural' habitats in Britain - heaths, ancient woodland, meadows and the like - are largely anthropogenic in character, and much of our most familiar wildlife, from rabbits to poppies, are alien introductions. The environments we cherish are neither natural nor timeless, but are enmeshed in human histories: even the kinds of tree most commonly found in the countryside are the consequence of human choice. The ways in which the environment was shaped by past management systems - to produce fuel, as much as food - are briefly explored; and the rise of 're-wilding' as a fashionable approach to nature conservation is examined, including its practical and philosophical limitations and its potential impacts on the conservation of cultural landscapes.
\end{abstract}

There are many reasons why we study history, but perhaps the most important is that it helps us to understand our present situation, and how the things we think of as 'normal' developed out of very different pasts. Only by appreciating how present 'reality' came into existence, came to be constituted, can we decide how to act in the present: what we need to do to maintain things as they are, or to change them in the future. In the case of the environment an area of pressing concern in both the popular and the political spheres - it has mainly been environmental historians like Paul Warde who have used the past to throw light on both the present, and the future. ${ }^{1}$ But other forms of history can also make a contribution. This article looks at the natural environment in England from the perspective of landscape history. It does not examine, in the way that Keith Thomas has so ably done, changes in social attitudes to and perceptions of 'the natural'. It focuses instead on the extent and character of human interventions in the natural environment in Britain over the centuries, and in so doing highlights how little was really 'natural' about it. ${ }^{2}$

Landscape history as a subject was first developed in the 1950s by social and economic historians like Maurice Beresford and, in particular, W.G Hoskins. ${ }^{3}$ These pioneers sought to explain aspects of the physical environment - the layout of villages, the shapes of fields, the varying chronologies of vernacular buildings in different areas - in terms of historical processes. But they also sought to use the physical environment to contribute to

\footnotetext{
${ }^{1}$ P. Warde, Energy Consumption in England and Wales 1560-2000 (Naples, 2006).

${ }^{2} \mathrm{~K}$. Thomas, Man and the Natural World: changing attitudes in England 1500-1800 (1983).

${ }^{3}$ M. Beresford, History on the Ground: six studies in maps andlLandscapes (1971); W. G. Hoskins, The Making of the English Landscape (London, 1955); W. G. Hoskins, Fieldwork in Local History (1967).
} 
wider debates in history, especially social and economic history. Such things as field patterns and settlement morphologies could be regarded as a kind of continuous above-ground archaeology. In Hoskins' words, the landscape was itself 'the richest historical record we possess'. ${ }^{4}$ The subject developed through the later twentieth century in new ways. Firstly, real field archaeologists began to be involved, people like the great Christopher Taylor. The earthworks of abandoned sections of villages were now interpreted alongside their surviving, upstanding portions; aerial photography and other non-invasive forms of archaeological investigation were embraced wholesale. ${ }^{5}$ Beresford and Hoskins had indeed used these approaches, but there was a new emphasis and rigour, and a new - longer - timescale, with many now suggesting that the 'making of the English landscape' had begun well before the Roman Conquest, rather than in Saxon times, as Hoskins had mainly believed. In addition, the late 1970s and 80s saw the increasing involvement of historical ecologists in the subject, most notably the late Oliver Rackham. ${ }^{6}$ Again, an interest in ecology was not entirely new. Max Hooper's work on how hedges could supposedly be dated by counting the number of species they contain (since comprehensively refuted) had been used by Hoskins. ${ }^{7}$ But landscape history now expanded to embrace the study of a whole range of 'semi-natural habitats' - woods, heaths, moors, meadows and the like.

Within such areas, particular forms of management, practised over long periods of time, created particular suites of species. Meadows, for example, were areas of low-lying grassland managed to produce a hay crop - vital as winter feed for livestock - and were accordingly closed to sheep and cattle during the spring and early summer. As a result, plants intolerant of grazing and trampling could flourish, flower and set seed without disturbance, many of them tall, bulky species like meadowsweet, globeflower or oxeye daisy. Over the centuries, a particular kind of management thus created a distinctive, rather beautiful, biologically diverse - but essentially unnatural environment. ${ }^{8}$

Heathland is another example. Heaths are largely treeless environments associated with poor, acid soils overlying porous sands and gravels. Their vegetation features a distinctive range of dwarf shrubs, principally heather or ling, gorse or furze, and broom, together with characteristic grasses such as sheep's fescue and common bent. ${ }^{9}$ Such environments sustain particular kinds of fauna - reptiles like the adder, birds like the Dartford warbler. Like meadows, heaths are essentially artificial environments. Most if not all examples developed from woodland, often in remote antiquity but sometimes as late as the sixteenth century. ${ }^{10}$ As trees died of old age, were barked by livestock or were cut down for timber and wood, regeneration

\footnotetext{
${ }^{4}$ Hoskins, Making of the English Landscape, 14.

${ }^{5}$ C. Taylor, Fieldwork in Medieval Archaeology (1974); Village and Farmstead: a history of rural settlement in England (1983).

${ }^{6}$ O. Rackham, Trees and Woodland in the British Landscape (1976); Ancient Woodland (1980); The History of the Countryside (1986).

${ }^{7}$ E. Pollard, M. D. Hooper and N. Moore, Hedges (1974).

${ }^{8}$ G. Peterken, Meadows (2013).

${ }^{9}$ N. Webb, Heathlands (1986); N. Webb, 'The traditional management of European heathlands', Journal of Applied Ecology, 35 (1998), 987-90.

10 J. A. Groves, M.P. Waller, M. J. Grant and J. E. Schofield, 'Long term development of a cultural landscape: the origins and dynamics of lowland heathland in southern England', Vegetation History and Archaeobotany, 21 (2012), 453-470; G. Barnes, P. Dallas, H. Thompson, N. Whyte and T. Williamson, 'Heathland and wood pasture in Norfolk: ecology and landscape history', British Wildlife 18 (2007), 395-403.
} 
was prevented by grazing and by further exploitation for fuel, with gorse, broom, heather now being harvested for domestic and industrial firing. Indeed, the importance of heaths as a fuel source in the pre-industrial period is often under-estimated by historians. In the early seventeenth century Thomas Blenerhasset memorably described how Horsford Heath in Norfolk was 'to Norwich and the Countrye heare as Newcastle coales are to London' ${ }^{11}$. Conversely, most heaths which escaped enclosure and 'improvement' in the eighteenth and nineteenth centuries, or the attentions of the Forestry Commission in the twentieth, have become colonised by secondary woodland during the last century or so, as the intensity of management has declined.

Mousehold Heath, also near Norwich, is a good example of all this. In the eighteenth century this was a huge tract of open heather, an iconic landscape painted by John Sell Cotman and other members of the Norwich School of painters. But its name incorporates the Old English term holt, 'a wood', and as late as the thirteenth century it was largely tree-covered. Local people exercised rights to graze livestock and gather fuel, and by the sixteenth century the whole 6,000 acres was largely treeless. ${ }^{12}$ Those parts of the heath lying close to Norwich survived enclosure and reclamation in the nineteenth century but, as management declined, they were rapidly colonised by birch, oak and sycamore. When conservation bodies attempt to clear some of this woodland, to restore areas of heath, they often face stiff opposition from local people exercised by this attack on 'nature'.

Ancient woodland is another important 'semi-natural habitat'. By the thirteenth century 'coppice with standards' woodland was common in Britain. In such woods, most of the trees and shrubs were cut down to a point at or near ground level on a rotation, usually of between eight and fifteen years, to produce a regular crop of 'poles' useful for fencing, tools, fuel and a host of domestic uses. ${ }^{13}$ Relatively small numbers of trees were allowed to grow as 'standards', for timber, and these were usually felled before they were 60 or 70 years of age. ${ }^{14}$ Because the regenerating coppice would be damaged by grazing, livestock was generally excluded by banks and fences for all or most of the time (unlike most heaths, medieval woods were enclosed land, part of the manorial demesne). The exclusion of stock, coupled with the recurrent cycles of light and shade resulting from coppicing, encouraged the development of a distinctive ground flora, characterised by wood anemone and other socalled 'ancient woodland indicators' ${ }^{15}$ Conversely, as intensive management has declined in the course of the last century, and as browsing by wild deer has increased, this distinctive flora has, in many cases, suffered a marked decline. ${ }^{16}$

Ancient woods are often thought of as the most natural of our habitats, fragments of the original forests which once covered the country - islands of preservation. But they are, perhaps, better considered as factories for the production of wood and timber which have, for

\footnotetext{
${ }^{11}$ T. Barrett Lennard, 'Two hundred years of estate management at Horsford during the $17^{\text {th }}$ and $18^{\text {th }}$ centuries', Norfolk Archaeology 20 (1921), 57-139.

12 Rackham, History of the Countryside, 299-303.

${ }^{13}$ Rackham, Ancient Woodland; G. Barnes and T. Williamson, Re-thinking Ancient Woodland (Hatfield, 2015).

${ }^{14}$ T. Williamson, G. Barnes and T. Pillatt, Trees in England: management and disease since 1600 (Hatfield, 2017), 81-2.

${ }^{15}$ Barnes et al., Rethinking Ancient Woodland, 6-11, 122-30.

${ }^{16}$ P. Doman, R. Fuller, R. Gill, D. Hooton and R. Tabor, 'Escalating ecological impact of deer in lowland woodland', British Wildlife 21 (2010), 242-54.
} 
the most part, become derelict. Their flora and fauna have been shaped in critical ways by this history. Survey after survey from medieval and post-medieval times shows that woods were overwhelmingly dominated by standards of oak. In contrast, the primeval woods of lowland England, before the advent of farming, had been dominated by small-leafed lime (Tilia cordata), now rather a rare species. ${ }^{17}$ Oak was widely planted or encouraged in managed woods because it provided the best structural timber. The coppiced understorey was, and is, variously constituted but likewise does not simply represent a managed version of the 'natural' vegetation. Numerous documentary references show that coppices were often weeded of unwanted shrub species or even extensively re-planted with useful ones like ash, hazel or hornbeam. A lease for South Haw wood in Wood Dalling in Norfolk, drawn up in 1612 , bound the lessee to plant sallows in cleared spaces following felling; the tithe files of 1836 describe how there were 35 acres of coppice wood in Buckenham in the same county, 'part of which has been newly planted with hazel'; while Lowe, writing about Nottinghamshire woods in 1794, described how 'vacancies are usually filled up with ash', and reported how, on one estate, the hazel and thorns were regularly stubbed up after the coppice was cut and 'and young ashes planted in their stead. By which mode ... these woods have been very considerably improved'. ${ }^{18}$ Vancouver in 1810 noted how, in Hampshire, some of the best ash shoots were retained when the coppice was felled, and plashed in the vacant spaces' to form new plants; a similar practice is recorded in Surrey woods in 1809. 19 Boys in 1805 suggested that many of the coppices in Kent were regularly supplemented with new plants simply because 'wood, like everything else, decays and produces fewer poles every fall, unless they are replenished' ${ }^{20}$ One Herefordshire landowner described in 1852 how 'the wood after successive fallages deteriorate as numbers of the old stools die and unless there is a considerable amount laid out in filling up the vacant places with young wood, ditching, etc a quantity of useless stuff such as birch, orl (alder?) and brambles grow up and consequently reduces the value of the wood'. ${ }^{21}$ Some important coppice species seem to have been relatively rare in woods before the high Middle Ages, most notably hornbeam. ${ }^{22}$

Indeed, so unnatural are woods - and all the other 'semi-natural habitats' found in Britain - that natural scientists, archaeologists and others now argue about what form, precisely, the landscape took before the adoption of farming from the fourth millennia BC. Until recently it was assumed that most of north-west Europe was originally covered with dense forest but this idea has been challenged by Frans Vera and others, who suggest that grazing by wild cattle, deer and other herbivores maintained a much more open landscape of grazed woodland, perhaps resembling savannah in places. ${ }^{23}$ The arguments marshalled in support of, and in opposition to, this view need not concern us here. Suffice it to say that

\footnotetext{
${ }_{17}$ O. Rackham, Woodlands (2011), 82-90; Williamson et al, Trees in England, 122.

${ }^{18}$ Norfolk Record Office BUL 2/3, 604X7; IR 29/5816; estate survey, 1752, Boughton House archives, no catalogue number. R. Lowe, General View of the Agriculture of the County of Nottingham (London, 1794), 34, 114.

${ }^{19}$ C. Vancouver, General View of the Agriculture of Hampshire (London, 1810), 297; W. Stevenson, General

View of the Agriculture of the County of Surrey (London, 1809), 127.

${ }^{20} \mathrm{~J}$. Boys, General View of the Agriculture of the County of Kent (London, 1805), 144.

${ }^{21}$ Herefordshire Archives and Records, A63/111/56/12.

${ }^{22}$ Williamson et al., Trees in England, 128-30.

${ }^{23}$ F. Vera, Grazing Ecology and Forest History (Wallingford, 2002).
} 
much of the evidence presented by Vera has been contested, or subject to different interpretations; while there are doubts about whether herbivore numbers would indeed have been enough to prevent substantial woodland regeneration, given the presence of significant hunter-gatherer populations. ${ }^{24}$ What is important is that the debate itself demonstrates how far we are removed from any truly 'natural' environment, unaffected by human agency.

This is true in other important ways. A surprising number of familiar plants and animals are introductions, made since late prehistory. We agonise about recent ones, invasive species like Japanese knot-weed, Himalayan balsam, Muntjac, Chinese water deer, grey squirrel, sika deer, or mink. Others, longer-established, are not unreasonably accepted as part of our native flora and fauna. ${ }^{25}$ An extraordinary range of familiar species are non-native: sycamore, sweet chestnut, the poppy (and most weeds of cereal crops), the snowdrop: even the lovely snakes-head fritillary may be an early garden escapee. ${ }^{26}$ The house mouse arrived in later prehistory, the black rat in Roman times and the brown rat in the 1720s (in 1777 Gilbert White considered a black rat killed at Shalden in Hampshire something of a rarity: 'the Norway rats destroy all the indigenous ones'). ${ }^{27} \mathrm{~A}$ number of alien animals were intentional introductions, including carp, fallow deer and the rabbit, made by the feudal elite in the Middle Ages as quarry, or as a food reserved for the privileged. ${ }^{28}$ The rabbit was initially so domesticated that it was kept in specially constructed mounds, complete with ready-made burrows. Rabbits had an important social significance now largely forgotten. Manorial lords holding a grant of free warren could, by law, establish warrens on common land regardless of the opposition of their tenants. Rabbits depleted the herbage rapidly, and soon spread more widely, damaging the crops growing in the neighbouring fields. ${ }^{29}$ Not surprisingly, warrens were regarded with particular hostility by peasant communities, and were frequently targeted by rebels and rioters. During the Peasants' Revolt of 1381 the rebels in St Albans placed one of the Abbot's rabbits, liberated from one of his many warrens, in the town pillory. ${ }^{30}$ So important were warrens as symbols of status that they were, before the eighteenth century, sometimes incorporated (like fish ponds and dovecotes) into the gardens and designed landscapes laid out around the homes of the wealthy. ${ }^{31}$ Only gradually did the rabbit spread into the wider countryside, in the course of the eighteenth and nineteenth centuries; and over the same period the importance of commercial warrens declined. The

\footnotetext{
${ }^{24}$ See, in particular, K. H. Hodder, P. C. Buckland, K. J. Kirby and J. M. Bullock, 'Can the pre-Neolithic provide suitable models for rewilding the landscape in Britain?', British Wildlife, 20, 5, 4-14; and the essays in I. Rotherham, Trees, Forested Landscape and Grazing Animals (2013).

${ }^{25}$ Invasive and Introduced Plants and Animals: human perceptions, attitudes and approaches to management, ed. I.D. Rotherham and R.A. Lambert (2011).

${ }^{26}$ R. Mabey, Flora Britannica (1998), 138-40; P. Oswald, 'The fritillary in Britain: a historical perspective' British Wildlife 3 (1992), 200-10.; D. A. Webb, 'What are the criteria for presuming native status?', Watsonia 15 (1985), 231-6; S. Thomas and T. Dines, 'Non-native invasive plants in Britain: a real, not imagined, problem', British Wildlife 21 (2010), 177-83.

${ }^{27}$ D. Yalden, The History of British Mammals (1999); D. J. Rackham, 'The introduction of the black rat into Britain', Antiquity 53 (1979), 112-20; W. Johnson (ed.) Gilbert White's Journal (1931), 46.

${ }^{28}$ C. Currie, 'The early history of carp and its economic significance in England', Agricultural History Review 39 (1991), 97-107; R. Liddiard, The Medieval Deer Park: new perspectives (Macclesfield, 2007); J. Sheail, Rabbits and their History (1971).

${ }^{29}$ T. Williamson, Rabbits, Warrens and Archaeology (Stroud, 2007).

${ }^{30}$ C. Omans, The Great Revolt of 1381 (Oxford, 1906), 462-3.

${ }^{31}$ C. Currie, 'Fish ponds as garden features', Garden History 18, 1 (1990), 22-33; Williamson, Rabbits,

Warrens and Archaeology, 164-75.
} 
rabbit's semi-domesticated status, and symbolic significance, is largely lost to us. Our joint history was forgotten as the species became part of our 'wildlife'.

A related problem is that we often think of the countryside as 'timeless', and its various constituent elements as being older and more stable than they actually are. In reality they have a history, because they are as much a part of the human world - the world studied by social, economic and agricultural historians - as they are of the 'natural'. That history is, in some cases, a relatively short one. Introductions aside, indigenous species have changed their habits and habitats, and their numbers, quite dramatically over recent centuries. The Act for the Preservation of Grain of 1597 allowed churchwardens to pay individuals for killing a range of specified birds and animals considered to be a threat to agriculture: the records of payments rendered are an important source, used to great effect by Roger Lovegrove in his book, Silent Fields: the long decline of a nation's wildlife. ${ }^{32}$ The wood pigeon, somewhat surprisingly given its modern status as a major agricultural pest, was not in the list of species which churchwardens could pay people for killing. This is because it was still rare, and still largely confined to woods. Its numbers rose steadily from the later seventeenth century, for it feasted on the leaves of turnips and other 'roots', and to some extent on clover, now growing in the winter fields. Gilbert White, writing about the Selbourne area in 1780, attributed its recent success to 'the vast increase in turnips', something which also explains, in part, the expansion of the rabbit in the wild. ${ }^{33}$

We have thus developed a bad habit of thinking of habitats, and their associated species, as being more timeless and more 'natural' - more divorced from human agency and human history - than they really are. But there is nothing new in this. The tendency to conflate 'nature', and the rural, developed in England and elsewhere in western Europe from the late seventeenth century, amongst a social elite whose lifestyle was increasingly focused on urban life, and divorced from the realities of agricultural production and the practicalities of land management. 'God made the country, man made the town' - William Cowper's famous adage - would make little sense to the farmer at work in the fields, still less to the agricultural labourer. ${ }^{34}$ In reality, both countryside and town were equally shaped by human agency. Indeed, the popular assumption that nature is found in the countryside, and not in towns and cities, is itself wrong or at least over-simple. Urban environments have their own distinct ecologies, critically shaped, as Owen Gilbert has demonstrated, by the individual histories of particular towns and cities. ${ }^{35}$ Our less intensively built-up developments, at least, may score well in terms of the opportunities afforded to wildlife. A study begun in the 1970s, by Jennifer Owen, of a small suburban garden in Leicester recorded - over a thirty-year period - no less than 2,673 species of flora and fauna, including 54 per cent of Britain's ladybird species, 23 per cent of its bees and 48 per cent of its harvestmen. And this was not a garden specially designed for wildlife. ${ }^{36}$ There are good reasons for resisting the ongoing

\footnotetext{
${ }^{32}$ R. Lovegrove, Silent Fields: the long decline of a nation's wildlife (Oxford, 2002).

${ }^{33}$ G. White, The Natural History and Antiquities of Selbourne in the County of Southampton (London, 1813), 113.

${ }^{34} \mathrm{~W}$. Cowper The Task (London, 1785), Book I, 37.

${ }^{35}$ O. Gilbert, The Flowering of the Cities: the natural flora of 'urban commons' (Peterborough, 1982); O. Gilbert, 'The ecology of an urban river', British Wildlife 3 (1992), 129-36; O. Gilbert, The Ecology of Urban Habitats (1989).

${ }^{36} \mathrm{~J}$. Owen, Wildlife of a Garden: a thirty year study (Peterborough, 2010).
} 
conversion of farmland to housing - issues of food security among them - but the maintenance of biodiversity may not always be the most important.

Since the start of the twentieth century, most conservationists have agreed that the best way of sustaining nature in Britain is to maintain as much as possible of the 'traditional' framework of the countryside, and to perpetuate the old, traditional methods of management of the kinds of key 'semi-natural environments' just discussed. But woods, heaths, meadows - even hedges - have been in retreat for over two centuries. Enclosure; the new forms of husbandry of the agricultural revolution; industrialisation and 'high farming'; the mechanisation of farming; have all rendered most of them rare, redundant or both. Those examples that have survived are always in danger of losing their distinctive characteristics through neglect. Woods, no longer coppiced, grow shady and species-poor; heaths and other areas of common land and rough grazing, no longer used for producing livestock, revert to secondary woodland. With practical and economic considerations no longer guaranteeing their survival, such environments can only be maintained through targeted subsidies to farmers and landowners, or by their acquisition and appropriate management as "nature reserves' by wildlife trusts and other conservation bodies.

Recently, however, such approaches have been challenged by the rise of 'rewilding', that is, the idea of creating tracts of land in which human influence is minimised or removed altogether. This approach first emerged in the United States but has become highly influential, in a variety of forms, in Europe and the UK over recent decades. ${ }^{37}$ It has begun to be put into practise at Oostvaardersplassen in the Netherlands, and at Ennerdale in Cumbria and on the Knepp Castle estate in Sussex. It has reached a wide audience through a number of books, most notably George Monbiot's Feral. ${ }^{38}$ Rewilding represents a very different approach to nature conservation. Rather than maintaining 'traditional' practices, human intervention is removed, key predators like the lynx or even the wolf are re-introduced, and nature is allowed to re-assert itself, in the form of the grazed savannahs and wood-pastures envisaged by Frans Vera. The long, shared history of humankind and other species is thus effectively denied and the two, in a spatial sense, are separated. And in one important way, as should by now be clear, such a stance has a certain persuasive logic, for most if not all 'traditional environments' are essentially arbitrary artefacts. If pre-industrial communities had exploited them in radically different ways, they would have had a different appearance and species composition.

There are, it should be noted, other ideas currently circulating about how to ensure a future for wildlife in Britain, including 'land sharing' - the concept of effectively 'zoning' the landscape to ensure that conservation is prioritised in some areas and abandoned altogether in others, to allow the intensive production of food. ${ }^{39}$ But in most versions, this

\footnotetext{
${ }^{37}$ D. Foreman, Rewilding North America: a vision for conservation in the 21st century (Washington, 2004$) ; \mathrm{P}$. Jepson, 'A rewilding agenda for Europe: creating a network of experimental reserves', Ecography 36 (2015), 18 ; M. Soulé and R. Noss, 'Rewilding and Biodiversity: complementary goals for continental conservation', Wild Earth 8 (1998), 19-28; J. D. Linnell, P. Kaczensky, U. Wotschikowsky, N. Lescureux, and L. Boitani, 'Framing the relationship between people and nature in the context of European conservation', Conservation Biology, 29 (2015), 978-985.

${ }^{38}$ G. Monbiot, Feral: Searching for Enchantment on the Frontiers of Rewilding (2015).

${ }^{39}$ H. von Wehrden, D. J. Abson, M. Beckmann, A. Cord and S. Klotz, 'Realigning the land-sharing/landsparing debate to match conservation needs: considering diversity scales and landuse history', Landscape
} 
approach effectively shades into the concept of 'rewilding', and the latter remains, in philosophical terms, the principal alternative to 'traditional' modes of conservation. Such debates about the place of nature in the modern world reflect the perceived crisis in conservation in the UK, with many key species currently undergoing catastrophic declines, as a consequence of large scale urbanisation, intensive farming, globalisation and, perhaps, ongoing climate change. ${ }^{40}$ Historians can usefully contribute to such discussions in a number of ways, beyond merely repeating the rather obvious observation that what we often think of as the natural world is arbitrary and contingent, and that humans and other organisms have shared a long history.

For example, teasing out the real character of environmental change over the last few centuries can allow us to see the current state of the environment in perspective, and in context, and thus help us to make more informed policy decisions. It is thus widely assumed that woodland cover in England has massively declined over the last century: that thousands of hectares of woodland have given way to urban development, quarries or intensive agriculture. But in reality, government surveys leave no doubt that the area of woodland has, in fact, roughly doubled in England since 1895, from around 5 to around 10 per cent of the land area. ${ }^{41}$ Some of this new woodland comprises conifer plantations, mainly established by the Forestry Commission in the period since 1922. But rather more represents secondary woodland which has regenerated naturally over abandoned heaths and other common land, or over derelict industrial land, in the course of the twentieth century. ${ }^{42}$ We can legitimately debate the ecological value of these various forms of woodland - which, in some cases at least, is unquestionably high - but it is useful to establish some basic, essentially historical, facts before we start. Dead wood is perhaps a more straightforward example. This is a really important resource, especially for forms of fungi and invertebrates. Ecologists understandably worry when land managers clear away fallen trees and branches. But there was unquestionably much less of this material in the past, when it was gathered on a massive scale as fuel by the local poor, who were regularly prosecuted for stealing it even from hedges.

An historical perspective is particularly useful when we consider the mounting concern about threats to tree health in Britain. Dutch elm disease first arrived in the UK in the 1920 s, but a more virulent strain appeared in the late 1960s, and within a decade had effectively wiped out elm as a tree. ${ }^{43}$ A series of epidemics has followed, including Phytophthora ramorum, leaf minor and canker in horse chestnut and, more recently, ash chalara (Hymenoscyphus fraxineus). All are caused by invasive organisms - fungi, bacteria, or insects - and have thus been seen as a consequence of globalisation, of the long-distance transport of timber and live plant materials, perhaps compounded by climate change. In addition, there are worries that tree health in Britain is suffering a more general deterioration, with recognition of such complex and diffuse conditions as 'oak decline', manifested in

Ecology 29 (6), 941-948; E.A. Law and K. A. Wilson, 'Providing Context for the Land-Sharing and LandSparing Debate', Conservation Letters 8, 6 (2015), 404-413.

${ }^{40}$ For a recent audit, see the 'State of Nature 2016' report: www.rspb.org.uk/our-work/stateofnature2016/

${ }^{41}$ Board of Agriculture Returns, 1896, 36; Forestry Commission, Forestry Statistics 2016 (Edinburgh, 2016).

42 Williamson et al., Trees in England, 172-82.

${ }^{43}$ C.M. Brasier, 'Ophiostoma novo-ulmi sp. nov., causative agent of current Dutch elm disease pandemics', Mycopathologia 115 (1991), 151-161. 
progressive thinning of the crown and general ill-health, leading to gradual death. Many of our hedgerow trees simply look ill. ${ }^{44}$

Systematic examination of the surviving documentary evidence leaves little doubt that, in this case, history provides no immediate solace. It is certainly true that before the start of the twentieth century trees often fell ill - sometimes in large numbers - and that we may have unrealistic expectations about tree health. The terms used to categorise trees in a survey of Staverton in Northamptonshire in 1835, for example, included 'decayed', 'damaged', 'small and very bad', 'very bad', 'decayed very bad' and 'dead', while at Mundford, Norfolk, in 1805 the surveyor was 'disappointed in the quantity of trees in the Square Plantation, finding such a quantity of dead ones'. ${ }^{45}$ Felling and sales records often refer to dead trees. The categories of trees sold from the Evan-Lomb estate Norfolk in 1835, for example, comprised 'Spruce, Hornbeam, dead ash, and elms' ${ }^{46}$ All this said, large-scale epidemics, embracing the whole country, do not seem to have occurred before the twentieth century, nor is there any clear earlier evidence for the long-distance movement of pathogens.

The first arrival was oak mildew, caused by the fungus Erysiphe alphitoides, probably of Asian origin, in $1908 .{ }^{47}$ Dutch elm disease, caused by the fungus Ophiostoma ulmi, disseminated by the elm bark beetle Scolytus, came next, in the 1920 s. It may have infected tree populations in Britain in earlier periods, although many supposed examples of previous outbreaks were probably caused by infestations of the beetle alone. It is noteworthy that European diseases were, at around the same time, spreading to other parts of the world. Beech bark disease, common in Europe, arrived in Nova Scotia in 1890; a European phytopthera appeared in Maine in $1930 .{ }^{48}$ This chronology suggests that the long-distance movement of wood and timber was not in itself the reason for the wide dispersion of pathogens (it had, indeed, been continuing for centuries), but rather the increasing speed of movement. By 1870 a number of inventions, including the screw propeller, the compound engine and the triple-expansion engine, made the shipping of bulk cargoes (as opposed to passengers) by steam, rather than wind, economically feasible, and goods thus travelled much faster. $^{49}$

In addition, it is useful to consider ways in which the changing character of British tree populations, over time, may have increased their vulnerability to disease. Maps, correspondence, and timber surveys from the period after c. 1600 reveal clearly that the lowland landscape has, at least since the sixteenth century, been overwhelmingly dominated by just three species: oak, ash and elm. But just as the kinds of tree and coppice found in

\footnotetext{
${ }^{44}$ C.M. Brasier, 'The biosecurity threat to the UK and global environment from international trade in plants', Plant pathology, 57 (2008), 792-808; R. Cheffings and C. M., Chalara. A summary of the impacts of ash dieback on UK biodiversity, including the potential for long term monitoring and future research on management scenarios, JNCC report No. 501 (Peterborough, 2014); S. Denman and J. F. Webber, 'Oak declines - new definitions and new episodes in Britain’, Quarterly Journal of Forestry, 103, 4 (2009), $285-290$.

${ }^{45}$ Northamptonshire Record Office, ZB 887; Norfolk Record Office, MS 13751, 40E3

${ }^{46}$ Norfolk Record Office, HNR 465/3/1.

${ }^{47}$ A. Mougou, C. Dutech and M. L. Desprez-Loustau, 'New insights into the identity and origins of the causal agent of oak powdery mildew in Europe', Forest Pathology 38, 4 (2014), 275-87.

$48 \mathrm{~J}$. Ehrlich, 'The occurrence in the United States of Gryptococcus fagi (Baer) Dougl, the insect factor in a menacing disease of beech', Quarterly Journal of Forestry 13 (1932), 73-80; K. P. Chester, 'The phtopthora disease of the Culla in America', Quarterly Journal of Forestry 11 (1930), 169-71.

49 J. Carlton. Marine Propellors and Propulsion (2012).
} 
woods were the consequence of selection and management, rather than being 'natural', the same was true of trees found in hedges and growing in pasture fields. Most were deliberately planted, others were self-seeding or suckering but, rather than being laid or coppiced with the other shrubs in the hedge, were preserved so that they could grow into trees. Blagrave urged the raising 'upon each Lordship or Pasture, Fuell and Firewood sufficient to maintain many Families, besides the Timber which may be raised in the Hedge-rows, if here and there in every Pearch be but planted an Ash, Oak, Elm ... ${ }^{50}$ Mortimer in 1707 thought that 'The best way of raising Trees in Hedges, is to plant them with the Quick' but he also gave advice on how to establish them 'wheare Hedges are planted already, and Trees are wanting'. ${ }^{51}$

Oak, ash and elm were favoured by land managers because they were catholic in their habits, grew reasonably quickly and, above all, because their wood and timber supplied most of the requirements of a pre-industrial economy. This said, in most regions they were accompanied by a small minority of other species, growing in hedges and pastures, which usually accounting for between 5 and 20 per cent of the total population. In different regions, trees like hornbeam, maple, black poplar or aspen were found alongside the three key species. But only in restricted districts did such alternatives rival or outnumber oak, ash and elm: examples include parts of the 'champion', open-field landscapes of the Midlands, where large numbers of willows on the meadows contrasted with sparser quantities of oak, ash and especially elm scattered through the open-fields; the Vale of Aylesbury, noted for its black poplars; and parts of the west Midlands and the Chilterns, where fruit trees often featured prominently in hedges. ${ }^{52}$

Another striking feature of the landscape was that, until the nineteenth century, there were generally very high densities of trees, in enclosed districts at least: commonly upwards of 25 per hectare. Moreover, a very high proportion of these (usually over 80 per cent in southern Britain) were managed as pollards, or aerial coppices, manly to provide fuel (as also were the hedges in which they grew). Economic necessity ensured that hedgerow trees were tolerated in large numbers even though this reduced the yield of crops in adjacent fields: 'Corn never ripens so kindly, being under the Shade and Droppings of Trees; the Roots likewise of the Trees spreading to some distance from the Hedges, do rob the Earth of what should nourish the Grain'. ${ }^{53}$ Individual pollarded trees were, in many cases, replaced after two centuries or so of cropping because their vitality declined and, as in woods, timber trees were generally felled before they were sixty years old. For centuries the countryside was thus characterised by very dense populations of young and regenerating trees, mainly of just three species.

From the end of the eighteenth century, improvements in transport infrastructure led to the spread of coal use, and pollarding rapidly declined. Pollards were removed wholesale so that hedges lost a high proportion of their trees. Timber trees remained, but their average age increased as the development of industrial saw mills (and the improvement of transport links to them) made it possible to process larger trunks. By the end of the nineteenth century, in many contexts, farmland trees were becoming less intensively managed, as landowners

\footnotetext{
${ }^{50} \mathrm{~J}$. Blagrave, The Epitome of the Art of Husbandry (London, 1675), 114.

${ }^{51} \mathrm{~J}$. Mortimer, The Whole Art of Husbandry (London, 1707), 309.

52 Williamson et al., Trees in England, 119-22.

${ }^{53}$ T. Nourse, Campania Felix (London, 1699), 27.
} 
concentrated their forestry activities in woods and plantations and as a new attitude to trees in the wider countryside developed, with a more general upsurge of conservationist enthusiasm. By the end of the nineteenth century the felling of prominent timber was being seen by many as a desecration of nature's beauties, rather than as good husbandry. Raymond Unwin famously boasted that only a single tree had been felled during the construction of Letchworth Garden City in north Hertfordshire in the first decades of the twentieth century.

All this means that, by the second half of the twentieth century, the countryside contained far more ageing trees than in previous periods, and it is possible that some tree 'illnesses' may not really be diseases at all. 'Oak decline', in particular, only affects middleaged or old trees. Few of these existed in the period before the mid-twentieth century. Moreover, when farmland trees were intensively managed they were usually taken down quickly if they fell ill, and sold for timber before they lost value. In 1676 Moses Cook described what we would today call 'oak decline', and advised on how the woodsman should deal with it:

When a Tree is at its full Growth, there are several signs of its decay, which give you warning to fell it before it can be quite decay'd; as in an Oak, when the top boughs begin to die ... but before it decays much, down with it, and hinder not your self. ${ }^{54}$

Today diseased trees are more likely to be left standing, either through neglect or to provide dead wood for wildlife, probably aiding the spread of infections. The intensively-managed tree populations of the past were thus probably healthier than those of today, largely left to their own devices. None of this, of course, can have any relevance to diseases like ash chalara, which mainly affect younger trees. But here, too, an historical perspective is informative. The species composition of our rural tree populations has little to do with nature - it was shaped by human choices, made for practical and economic reasons. We can now make different choices, for different reasons, and one obvious one would be to diversify our planting to reduce vulnerability; to increase the proportion of the 'minority' trees, like hornbeam or wild service or small-leafed lime, to ensure a greater degree of resilience in the face of future epidemics.

In innumerable other ways an historical perspective can help us to understand key aspects of the rural environment, and how these were shaped by past practise, allowing us to make meaningful decisions about future management. Knowledge of this kind allows us to understand, in particular, the complexity and diversity of past management systems, the intricate and varied ways in which 'semi-natural habitats' were exploited. I noted earlier how heaths were maintained by grazing and fuel cutting, but there was much variation in the balance between these two uses, and there were several other ways in which such environments were exploited. The precise combination of uses varied from place to place, and from period to period, because heaths were integrated into local economies and farming systems, so that not all 'heaths' were the same. ${ }^{55}$ The ecologist Paul Dolman and colleagues

\footnotetext{
${ }^{54}$ M. Cook, On the Manner of Raising, Ordering and Improving Forest-Trees (London, 1676), 171.

${ }^{55}$ R. J. Fuller, T. Williamson, G. Barnes and P. Dolman, ' Human activities and biodiversity opportunities in pre-industrial cultural landscapes: relevance to conservation', Journal of Applied Ecology, 54, 2 (2017), 459469.
} 
recently carried out a 'biodiversity audit' of the area called Breckland in East Anglia, still known for its heathland. They noted that a number of important species of plant and invertebrate, largely restricted to this region, had declined significantly over recent decades. Most of the surviving heaths in the area are maintained by continuous, light grazing by sheep, a prescription intended to ensure a reasonably high growth of heather. But many of the characteristic Breckland species in fact depend on the juxtaposition of areas of stable heather, and areas of regular disturbance ${ }^{56}$ From an historical perspective this is unsurprising - until the nineteenth century the region was characterised by extensive rabbit farms, characterised by much disturbed ground, and large areas of heath were sporadically cultivated as outfield 'brecks' ${ }^{57}$ It was thus a region in which, for centuries, stable heathland indeed existed beside areas of disturbance. 'Traditional' management needs to be historically informed: we need to know precisely how distinctive habitats were managed and thus shaped in the past if we are to manage them effectively into the future. Yet at the same time, understanding past management systems and what, precisely, they achieved in terms of biodiversity may have another purpose. It may allow us to design, in some circumstances, entirely new forms of management that mimic - perhaps in new combinations - their principal features. Historical research can also highlight some more general, shared characteristics of past management systems, including variation in character over short distances, repeated disturbance, and constant nutrient and biomass depletion. ${ }^{58}$

Traditional management, characterised by repeated and intensive interventions by humans, represents a clear antithesis to 'rewilding'. But it is important to emphasise that little research has been carried out to demonstrate the superiority of either approach in terms of wildlife conservation. Indeed, much of the enthusiasm for 'rewilding' has been based more on emotion - the 'call of the wild' - than on any careful assessment of what it actually achieves. In fact, it is arguable that the conversion of the 'natural' landscape - whatever its precise character - to farmland increased rather than lessened biodiversity, and that agricultural landscapes, at least those managed on 'traditional' lines, provide a greater diversity of habitats and niches, at a range of spatial scales, than would be afforded by the secondary grazed woodland of rewilded reserves. ${ }^{59}$ They certainly sustain the particular species which we now think of as part of our common 'natural' inheritance, and which have become culturally important to us. Many of these, like the flowers characteristic of meadows, were probably rare in the pre-agricultural landscape. The highest levels of species diversity are to be found in fine-grained habitat mosaics, with an abundance of edges and juxtapositions, each endlessly disturbed and never reaching equilibrium: the kinds of habitats generated by traditional management systems. This is a particularly important consideration, perhaps, across the more populous areas of Europe, where land is in short supply and the

\footnotetext{
${ }^{56}$ P.M.Dolman, C. Panter and H.L Mossman, Securing Biodiversity in Breckland: Guidance for Conservation and Research. First Report of the Breckland Biodiversity Audit (Norwich, 2010); P. M. Dolman, C. Panter and H. L Mossman, 'The biodiversity audit approach challenges regional priorities and identifies a mismatch in conservation', Journal of Applied Ecology, 49 (2012), 986-997.

57 J. Belcher, "The Greatest Wealth of our Country": the fold course in East Anglia'. Unpublished PhD thesis, University of East Anglia, 2016; M. Bailey, A Marginal Economy? East Anglian Breckland in the Later Middle Ages (Cambridge, 1989).

${ }^{58}$ Fuller et al., 'Human activities and biodiversity opportunities', 468-9.

${ }^{59}$ ibid.
} 
competing demands made on it increasing. In such circumstances, 'rewilded' reserves, complete with reintroduced alpha-predators, would tend of necessity tend to be placed in more marginal areas, agriculturally and spatially. While 'rewilding' should, and will, have an important place in future conservation policies, most people will always experience nature in more domestic settings - in the countryside or on the urban fringe - and this is where a significant proportion of our conservation energy should continue to be concentrated. The more we accept the 'rewilding' approach, the more we may be encouraging a situation developing across much of the globe anyway for economic and technological reasons - in which the landscape comprises three sharply contrasting types of habitat: densely-settled urban areas; intensively farmed countryside; and 'wilderness', often by definition remote from human habitation (the policy of 'land sharing' is problematic for similar reasons).

Perhaps more importantly from the historian's point of view, we need to emphasise that 'rewilded' landscapes can never closely resemble the natural landscape, in the sense of the grazed woodlands which existed in remote prehistory, before the advent of farming. To use George Peterken's terms, 'future nature' would of necessity be radically different from 'past nature'. ${ }^{60}$ 'Rewilded' reserves would contain a range of animals which were not naturally present in this country, including (as we have seen) both species of rat, the rabbit, the grey squirrel, fallow deer, muntjac, sika deer, and Chinese water deer. They would boast a flora featuring an even greater range of naturalised species, such as sycamore and rhododendron - especially the latter, given that many areas targeted for large-scale 'rewilding' are in upland districts, where this plant has become seriously invasive. ${ }^{61}$ Indeed, in an important sense 'rewilded' reserves would still be cultural landscapes, for the motley array of plants and creatures living within them would represent a dim memory of specifically human actions and desires, ranging from medieval hunting fashions to Victorian gardening fads. They would still have a history. But this in turn raises the more profound question of how far even the landscapes of the Mesolithic period - post-glacial, but prefarming - were really 'natural', in the sense of being unshaped by human activities, given the sheer scale of the impact made by hunter-gathers on the environment, together with the accumulating evidence for such an impact in Britain itself. ${ }^{62}$ Since the ice retreated, this country may always have had an ecology which was extensively, fundamentally, shaped by man.

\footnotetext{
${ }^{60}$ G. F. Peterken, Natural Woodland: Ecology and Conservation in Northern Temperate Regions (Cambridge, 1996), 13.

${ }^{61}$ I. D. Rotherham, 'Rhododendron gone wild: conservation implications of Rhododendron ponticum in Britain', Biologist 48 (2001), 7-11.

${ }^{62}$ A. G. Brown, 'Clearances and clearings: deforestation in Mesolithic/Neolithic Britain', Oxford Journal of Archaeology 16 (1997), 133-146; C. Caseldine and J. Hatton, 'The development of high moorland on Dartmoor: fire and the influence of Mesolithic activity on vegetation change', in F. M. Chambers (ed.) Climate Change and Human Impact on the Landscape (London, 1993), 119-131; J. B. Innes and I. G. Simmons, 'Mid-Holocene charcoal stratigraphy, fire history and palaeoecology at North Gill, North York Moors, UK', Palaeogeography, Palaeoclimatology, Palaeoecology 164 (2000), 151-165; H. T. Lewis, 'Fire technology and resource management in aboriginal North America and Australia', in N. M. Williams and E. S. Hunn (eds) Resource Managers: North American and Australian Hunter-Gatherers (Boulder, CO, 1982), 45-67; S. K. Lyons, F. A. Smith and J. H. Brown, 'Of mice, mastodons and men: human-mediated extinctions on four continents' Evolutionary Ecology Research 6 (2004), 339-358.
} 
One of the most worrying aspects of 'rewilding' is what it implies about the past. The creation of extensive 'rewilded' reserves must inevitably involve the wholesale disappearance of many elements of the historic landscape - hedges, traditionally managed woodland, field patterns, landscape parks. What, one wonders, would W. G. Hoskins have made of it all? Rural landscapes embody values other than those relating to the natural world. They have important cultural and historical associations. They can, in the hands of great landscape designers like Lancelot 'Capability' Brown, in themselves be a form of art. While few advocates of rewilding would perhaps wish to allow grazed woodland to return to the bleak Howarth Moors, inspiration for Bronte's Wuthering Heights; or to Dedham Vale, the subject of so many of John Constable's paintings; in many other contexts the erasure of all signs of the human past appears to be actively welcomed, precisely because it serves to foster the 'experience' of wilderness. All this marks a significant and worrying shift in the relationship between ecology and history, for in the twentieth century a succession of conservationists and historical ecologists, most notably Oliver Rackham, saw the landscape as something which embodies both natural and human history, the two connected in complex ways.

Perhaps the most interesting question of all is why this is happening now. Why, at this particular point in history, should so many people wish to adopt approaches to conservation based on a sharp separation of man and nature? 'Rewilding' represents, to some extent, a rational response to the fact that in western Europe most habitats are arbitrary and anthropogenic and can only be maintained by continuing management practices which have been rendered redundant by economic and technological change. Connected with this is a realisation that some of these habitats, while long-established and to an extent culturally valued, are not in fact very biodiverse, and that some of the land they occupy might be better used. There are more than 45,000 square kilometre of upland moor in Britain, for example, much of it species-poor. Allowing a proportion to regenerate to grazed woodland would increase biodiversity and also bring additional benefits, in terms of reducing run-off after rains and thus reducing the risk of flooding in the surrounding areas of lower ground. But the popularity of 'rewilding' probably owes less to scientific argument, and more to shifts in popular attitudes towards the environment. The overwhelming majority of the population in Britain, as elsewhere in western Europe, is now urban. Many people have little experience of or affinity with the countryside, and few now work on the land. Some have little connection with any specific place, in our socially mobile and culturally complex world: in Goodhart's terms, they are 'anywhere' rather than 'somewhere' people. ${ }^{63}$ Much of rural Britain is today mainly occupied by middle-class incomers, and large tracts of the countryside have effectively been suburbanised, in social terms at least. All this has perhaps encouraged a belief that nature can only really be experienced in raw and dramatic form, as spectacle, and in places remote from humans, rather than in 'the countryside', even on nature reserves. Such an experience can already be supplied by the Knepp estate, with its organised 'safari' tours of the 'wilderness' which is gradually regenerating over abandoned farmland a short drive from central London. But whatever the precise explanations for the rise of 'rewilding', at this time

${ }^{63}$ D. Goodhart, The Road to Somewhere: the populist revolt and the future of politics (2017). 
of environmental crisis historians need to make their own distinctive contribution to debates about the future of nature, in Britain and beyond. 